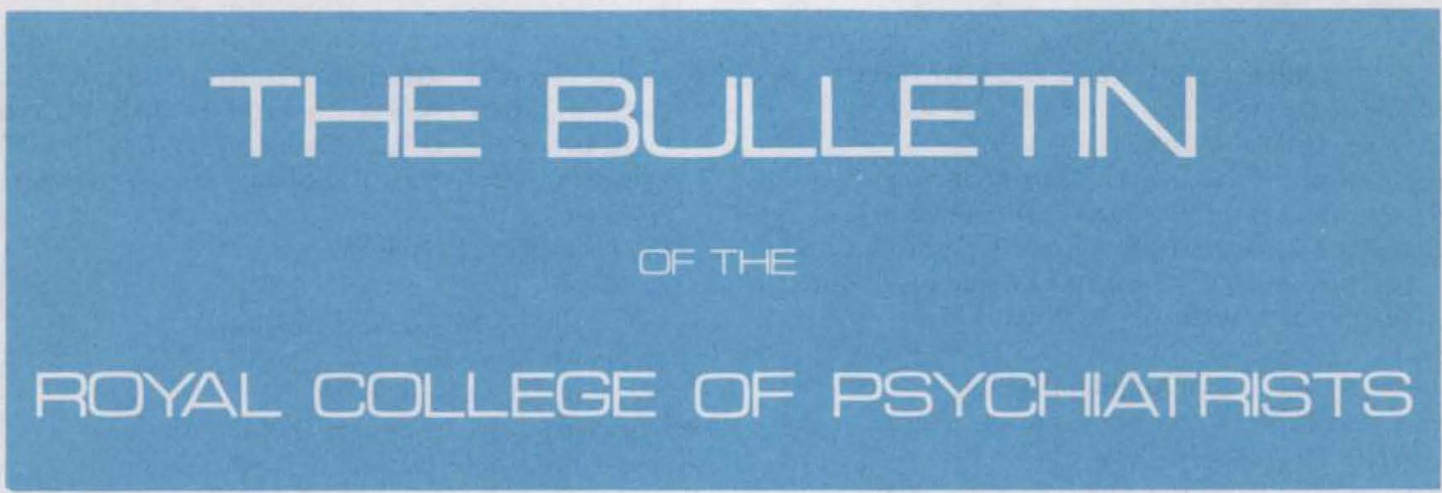

\title{
COLLEGE NEWS \\ ELECTION OF HONORARY OFFICERS \\ ELECTIONS TO FILL VACANCIES ON THE COURT OF ELECTORS AND FOR ELECTED MEMBERS OF COUNCIL
}

Fellows and Members of the College are reminded of their rights in connection with the forthcoming elections for the offices of Dean, Registrar, Treasurer, Editor, Librarian, and Sub-Deans. The relevant sections of the Bye-Laws and Regulations are printed on page 52 of this issue.

In accordance with Bye-Law XV Dr Wilfrid Warren, having held office as Treasurer for seven years, is not eligible for re-election. Dr C. P. Brook has served for five years as Sub-Dean and is not eligible for reelection. (Bye-Law XVIII). The other Honorary Officers are eligible.
The nominating meeting of Council will be held on 14 March 1979, and the last date for receiving nominations will therefore be 12 April 1979 .

Fellows and Members are also reminded that nominations may be submitted for vacancies on the Court of Electors and for Elected Members of Council. The relevant Bye-Law and Regulation will be found on page 52 of this issue. Lists of Officers and members of Council and the Court of Electors were published in the Bulletin for January 1979.

\section{Contents}

College News:

Election of Honorary Officers: Elections to fill Vacancies on the Court of Electors and for Elected Members of Council 37 and 52

Officers of Divisions, Sections and Groups

Parliamentary News (to Christmas Recess, 1978)

Spring Quarterly Meeting concessionary travel: a correction

The College's Comments on the Report of the Royal Commission on Gambling: Summary

Psychotherapy Section

Workshop in Research Methods for Psychiatry
Regional Secure Units:

1. Rainford Ward, Rainhill Hospital,

Merseyside; by Dr J. Higgins

2. The Lyndhurst Unit at Knowle Hospital,

Fareham, Hants; by Dr M. Faulk

The Use and Misuse of Confidential Information; by Dr Zaida M. Hall

Safeguarding Confidentiality: a reply; by Professor J. K. Wing

Correspondence

Forthcoming Events

51

The views expressed in articles published in the Bulletin (except official College material) are the auphors' own and do not necessarily represent College Policy. 